\title{
New faunistic records of Gasteracantha Sundevall, 1833 and Macracantha Simon, 1864 species (Araneae: Araneidae) from Vietnam
}

\section{Новые фаунистические находки видов Gasteracantha Sundevall, 1833 и Macracantha Simon, 1864 (Araneae: Araneidae) из Въетнама}

\author{
Steven H. Williams \\ Стивен Г. Вияьямс
}

Oxford University Museum of Natural History, Parks Road, Oxford, OX1 3PW, UK. E-mail: steven.williams-2015@brookes.ac.uk

KEY WORDS: Arachnida, Gasteracanthinae, orb-weaving spiders, faunistics.

КЛЮЧЕВЫЕ СЛОВА: Arachnida, Gasteracanthinae, пауки-кругопряды, фаунистика.

ABSTRACT. The Indomalayan spiny orb-weaver Gasteracantha hasselti C.L. Koch, 1837 is recorded from Vietnam for the first time, with notes on new faunistic records of four other Vietnamese Gasteracanthinae. The samples come from across Vietnam and are mainly from the expeditions of the Russia-Vietnam Tropical Centre in 2000-2016.

РЕЗЮМЕ. Индомалайский вид шипастого кругопряда Gasteracantha hasselti C.L. Koch, 1837 впервые отмечен во Вьетнаме, с указанием новых фаунистических находок для четырех других видов вьетнамских Gasteracanthinae. Изученные образцы были собраны во время экспедиций Русско-Вьетнамского Тропического Центра в 2000-2016.

\section{Introduction}

The genus Gasteracantha Sundevall, 1833 (Araneidae: Gasteracanthinae) is currently represented by over 100 species, with a world-wide distribution and the highest diversity in the tropics [WSC, 2017]. This publication, following on from the work of Logunov and Jäger [2015], adds a new species record of Gasteracantha hasselti C.L. Koch, 1837 to the checklist of Vietnamese spiders by Ono et al. [2012]. The new record brings the total number of Gasteracantha species from Vietnam to six: G. diadesmia Thorell, 1887; G. frontata Blackwall, 1864; G. hasselti; G. kuhli C.L. Koch, 1837; G. sauteri Dahl, 1914; and G. theisi Guérin, 1838. Also included in this paper are the faunistic records of Macracantha arcuata (Fabricius, 1793) that belongs to the same subfamily Gasteracanthinae.

The studied material was mainly collected by Alexei V. Abramov (St. Petersburg, Russia) during the 2000 2016 expeditions of the Russia-Vietnam Tropical Centre (Hanoi). The material is housed in the collection of the Zoological Museum of the Moscow State Universi- ty, Russia (ZMMU; curator K.G. Mikhailov) and at the Manchester Museum, United Kingdom (MMUE; curator D.V. Logunov).

In the following list of species, the numbers in square brackets after the detailed information on each locality correspond to those given on the map.

\section{Species review}

Gasteracantha diadesmia Thorell, 1887 Map.

MATERIAL. VIETNAM: 1 + 1 juv. (ZMMU), Ba Vi Distr., Son Kim Community, c. $50 \mathrm{~km} \mathrm{~W}$ of Hanoi, Ba Vi Nat. Park, nr. Tanh Linh Vil. $\left(21^{\circ} 05^{\prime} 49.6^{\prime \prime} \mathrm{N}, 105^{\circ} 24^{\prime} 07.3^{\prime \prime} \mathrm{E}\right)$ [3], $100 \mathrm{~m}$ a.s.l., May 2013, A.V. Abramov; 5 우, 6 ㅇjuv. (ZMMU), Ha Tinh Prov., Huong Son Distr., Son Kim Community, c. $10 \mathrm{~km} \mathrm{~S}$ of Nuoc Sot Vil. $\left(18^{\circ} 22^{\prime} \mathrm{N}, 105^{\circ} 13^{\prime} \mathrm{E}\right)$ [5], $200 \mathrm{~m}$ a.s.l., 11-26.04.2000, A.V. Abramov; 1 (ZMMU), Cuc Phuong Reserve, 1980ies, Zlotin

COMMENTS. Known from India to the Philippines [WSC, 2017]; in Vietnam, recorded from Saigon, Luc Nam, Tuyen-Quang, Ha Tinh Province, Ba Vi District and Cuc Phuong Reserve [Simon, 1904, 1909; present data]. Roy et al. [2017] is the most recent publication to illustrate the species.

Gasteracantha hasselti C.L. Koch, 1837 Figs 1-7, Map.

MATERIAL. VIETNAM: 1 q (MMUE, G7573.52), Tuyen Quang Prov., c. $5 \mathrm{~km} \mathrm{E}$ of Na Hang $\left(22^{\circ} 20^{\prime} 59^{\prime \prime} \mathrm{N}, 105^{\circ} 25^{\prime} 36^{\prime \prime} \mathrm{E}\right)$ [1], 290 m a.s.1., 4-13.11.2015, D.V. Logunov; 1 (ZMMU), Phu Tho Prov., Thanh Son Distr., Xuan Son Nat. Park $\left(21^{\circ} 08^{\prime} 11^{\prime \prime} N\right.$, $104^{\circ} 56^{\prime} 11^{\prime \prime}$ ) [2], 300-400 m a.s.1., July 2014, A.V. Abramov; 2 ofjuv. (ZMMU), Ba Vi Distr., c. $50 \mathrm{~km}$ W of Hanoi, Ba Vi Nat. Park, nr. Ba Vi Resort $\left(21^{\circ} 04^{\prime} 57.9^{\prime \prime} \mathrm{N}, 105^{\circ} 22^{\prime} 54.1^{\prime \prime} \mathrm{E}\right)$ [3], 350$400 \mathrm{~m}$ a.s.1., May 2013, A.V. Abramov; 1 (ZMMU), Hai Phong Prov., Ca Ba Island, Ca Ba Nat. Park, c. $10 \mathrm{~km} \mathrm{NW}$ of Ca Ba City $\left(20^{\circ} 47^{\prime} 56^{\prime \prime} \mathrm{N}, 106^{\circ} 59^{\prime} 47^{\prime \prime} \mathrm{E}\right)$ [4], $50 \mathrm{~m}$ a.s.l., October 2011, A.V. Abramov; 1 juv. (ZMMU), Kon Tum Prov., Kon Plong Distr., c. $14 \mathrm{~km} \mathrm{~N}$ of Kon Plong Town $\left(14^{\circ} 43^{\prime} 20^{\prime \prime} \mathrm{N}, 108^{\circ} 18^{\prime} 58^{\prime \prime} \mathrm{E}\right)$ [6], 1030 

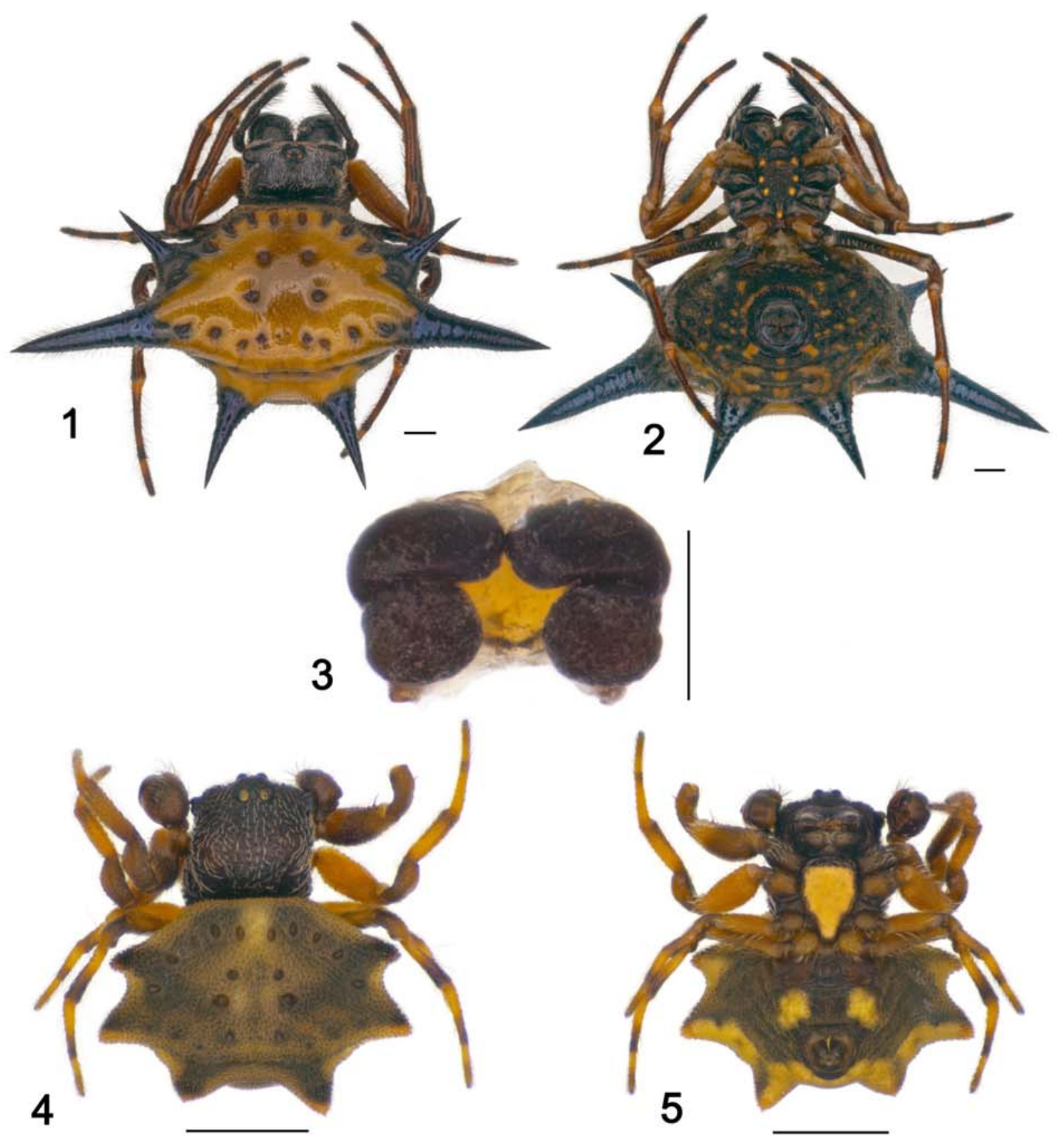

6
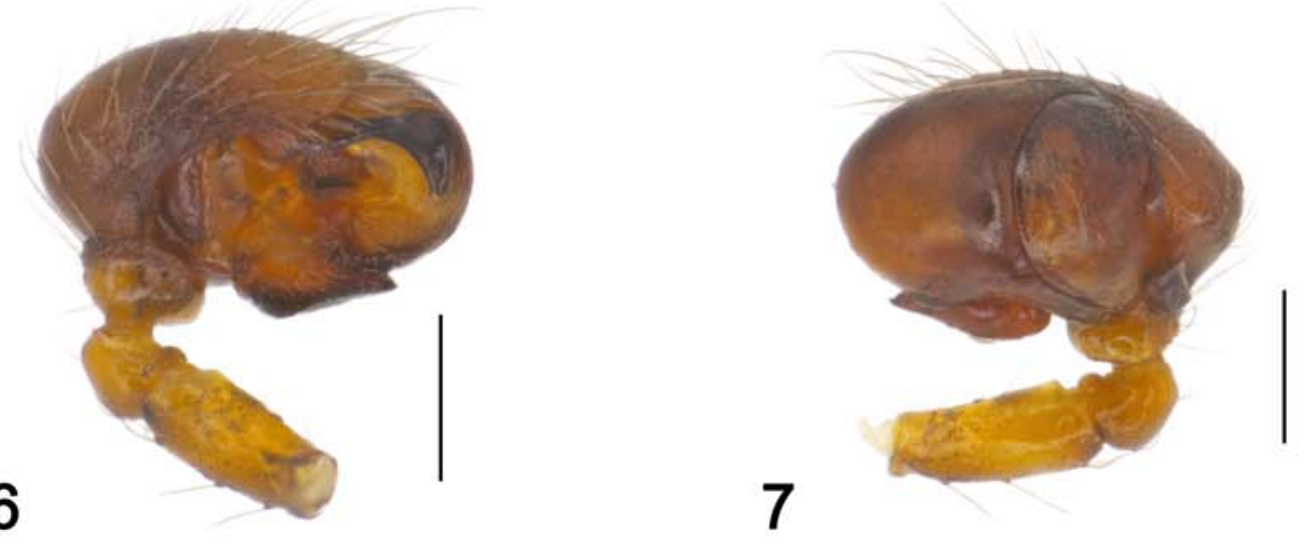


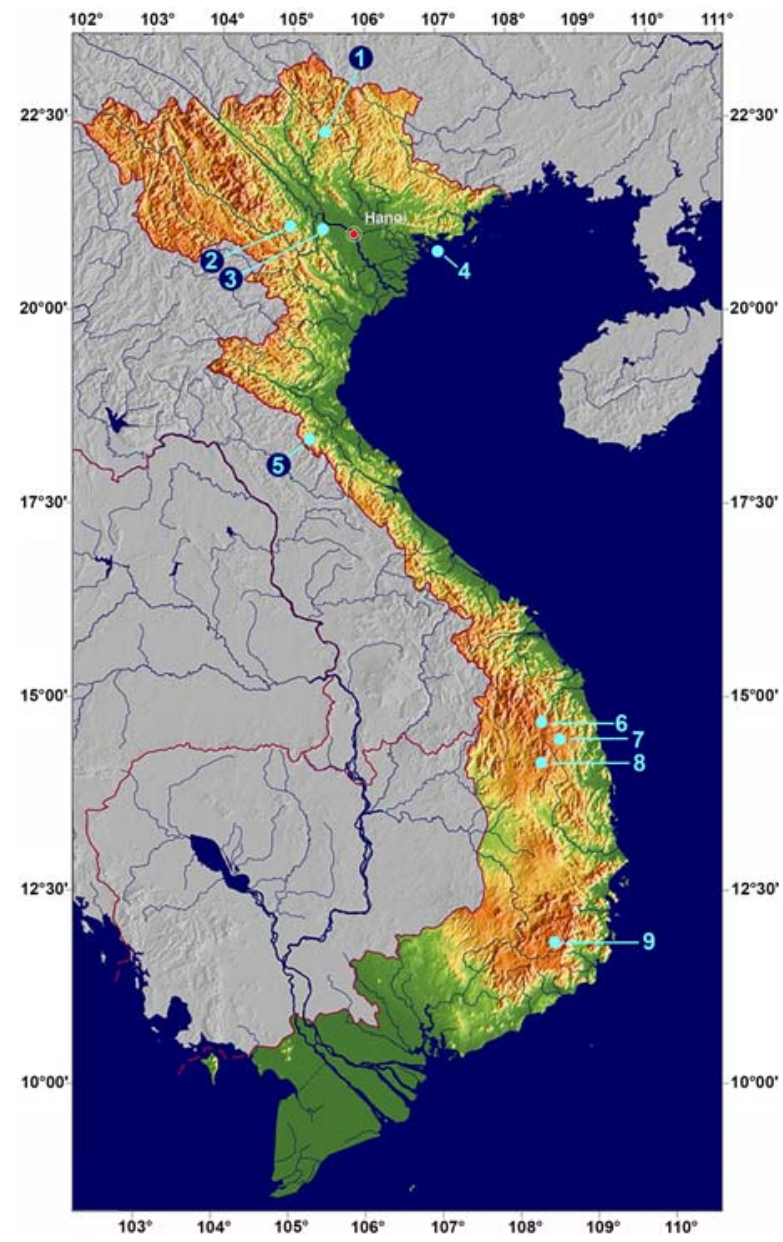

Map. New collecting localities of the studied Gasteracantha and Macracantha species in Vietnam: G. hasselti $(1,2,3,4,6,7$, 8, 9); G. diadesmia $(3,5) ; G$. kuhli (3); G. sauteri $(2,5)$; and $M$. arcuata $(6,7,8)$

Карта. Новые точки сбора изученных видов Gasteracantha и Macracantha во Вьетнаме: G. hasselti $(1,2,3,4,6,7,8,9) ; G$. diadesmia $(3,5)$; G. kuhli (3); G. sauteri $(2,5) ;$ M. arcuata $(6,7,8)$.

m a.s.1., 9-23.04.2015, A.V. Abramov; 1 ○', 2 ㅇ (MMUE, G7579.1, 4, 9), Gia Lai Prov., c. 40 km N of K'Bang Town, Kon Chu Rang Nat. Reserve $\left(1^{\circ} 30^{\prime} 19^{\prime \prime} \mathrm{N}, 108^{\circ} 32^{\prime} 28^{\prime \prime} \mathrm{E}\right)$ [7], $1200 \mathrm{~m}$ a.s.1., 24.05-2.06.2016, A.V. Abramov; 2 of, 1 ojuv. (MMUE, G7579.2-3), Gia Lai Prov., Mang Yang Distr., c. $42 \mathrm{~km} \mathrm{NE}$ of Pleiku, W part of Kon Ka Kinh National Park $\left(14^{\circ} 12^{\prime} 12^{\prime \prime} \mathrm{N}\right.$, $108^{\circ} 18^{\prime} 54^{\prime \prime} \mathrm{E}$ ) [8], $900 \mathrm{~m}$ a.s.1., 10-21.05.2016, A.V. Abramov; 1 ojuv. (ZMMU), c. $7 \mathrm{~km} \mathrm{~S}$ of Da Lat Town, Prenn Waterfall $\left(11^{\circ} 52^{\prime} 4^{\prime \prime} \mathrm{N}, 108^{\circ} 28^{\prime} 1^{\prime \prime} \mathrm{E}\right)$ [9], 6.03.2012, T.K. Tuneva.

COMMENTS. Known from India, China to Moluccas [WSC, 2017]; a new species record to Vietnam, where it has been found in Hai Phong Province, South of Da Lat Town, Ba Vi District, Phu Tho Province, Kon Tum Province, Tuyen Quang Province and Gia Lai Province [present data].

The images provided here (Figs 1-7) are to assist in the species identification. The material studied agrees with the original descriptions provided by C.L. Koch $[1837,9]$ and Thorell $\left[1859, O^{1}\right]$ and is also supported by the most recent publications illustrating this species [Yin et al., 2012; Sen et al., 2015].

Ono et al. [2012: 19] listed a record of Gasteracantha theisi from Vietnam, and it was stated that the species was only "recorded by Hogg (1922)" and that it was previously identified as Plectana praetextata Walkenaer, 1841. The name 'praetextata' is currently synonymised with $G$. theisi by Thorell [1881]. However, in his 1859 publication Doleschall listed a 'Plectana praetextata Var. A.' [Doleschall, 1859: 42] and the figures illustrated a single female example of $G$. theisi (Plate 8, Fig. 4) and one with the appearance of G. hasselti (Plate 11, Fig. 6); it could be assumed that this is just a 'variation'. It is possible that Hogg used this publication for his identification of the specimens from Vietnam and that the record could simply be a misidentification of $G$. hasselti due to the confusion in Doleschall's work. An effort has been made to locate the 'two female' specimens Hogg referenced in his publication. Several museums have been contacted (e.g. the Natural History Museum London and the Australian Museum) that Hogg is known to have visited, but none of the curators were aware of any putative Hogg material. There is the potential that these specimens will be discovered and the truth about the identification of $G$. theisi from Vietnam will be sorted, but at present $G$. hasselti is added to the recorded list in addition to G. theisi. The species G. hasselti and G. theisi are distinct from each other and it is only the identification of the specimens that provide the Vietnamese record for $G$. theisi that are being questioned.

\section{Gasteracantha kuhli C.L. Koch, 1837 Map.}

MATERIAL. VIETNAM: 2 우, 1 +juv. (ZMMU), Ba Vi Distr., Son Kim Community, c. $50 \mathrm{~km} \mathrm{~W}$ of Hanoi, Ba Vi Nat. Park, nr. Tanh Linh Vil. $\left(21^{\circ} 05^{\prime} 49.6^{\prime \prime} \mathrm{N}, 105^{\circ} 24^{\prime} 07.3^{\prime \prime} \mathrm{E}\right)$ [3], $100 \mathrm{~m}$ a.s.1., May 2013, A.V. Abramov; 1 +, 1 fjuv. (ZMMU), Cuc Phuong Reserve, 1980ies, Zlotin.

COMMENTS. Known from India to Japan and the Philippines [WSC, 2017]; in Vietnam, recorded from "Cambodge", "Cochinchine", Hanoi, Luc Nam, Tuyen Quang, Lao Kai (under currently synonymised names: Gasteracantha annamita Simon, 1886 and G. leucomelas Doleschall, 1859), Vinh Phuc Province, Ha

Figs 1-7. General appearance and copulatory organs of Gasteracantha hasselti C.L. Koch, 1837 from Vietnam: 9 from Xuan Son National Park in Phu Tho Province (ZMMU) (1-3) and $0^{7}$ from Kon Chu Rang Nature Reserve in Gia Lai Province (MMUE, G7579.9) (47): 1, 4 - body, dorsal view; 2, 5 - ditto, ventral view; 3 - spermathecae, dorsal view; 6 - male palp, prolateral view; 7 - ditto, retrolateral view. Scale bars: $(1,2,4,5) 1 \mathrm{~mm},(3,6,7) 0.25 \mathrm{~mm}$.

Рис. 1-7. Общий вид и копулятивные органы Gasteracantha hasselti C.L. Koch, 1837 из Вьетнама: ㅇ из национального парка Хуан Сон в провинции Футо (ZMMU) (1-3) и О из национального парка Кончу в провинции Гиалай (MMUE, G7579.9) (4-7): 1, 4 тело, вид сверху; 2, 5 - тоже, вид снизу; 3 - сперматека, вид сверху; 6 - пальпа самца, пролатерально; 7 - тоже, ретролатерально. Масштаб: $(1,2,4,5) 1 \mathrm{мм},(3,6,7) 0,25$ мм. 
Giang Province, Ba Vi District and Cuc Phuong Reserve [Simon, 1886, 1909; Pham Dinh et al., 2007; present data]. Roy et al. [2017] is the most recent publication to illustrate the species.

\section{Gasteracantha sauteri Dahl, 1914 Map.}

MATERIAL. VIETNAM: 1 (ZMMU), Phu Tho Prov., Thanh Son Distr., Xuan Son Nat. Park $\left(21^{\circ} 08^{\prime} 11^{\prime \prime} N, 104^{\circ} 56^{\prime} 11^{\prime \prime} \mathrm{E}\right)$ [2], 300-400 m a.s.1., July 2014, A.V. Abramov; 1 9juv. (ZMMU), Ha Tinh Prov., Huong Son Distr., Son Kim Community, c. $10 \mathrm{~km} \mathrm{~S}$ of Nuoc Sot Vil. (18 $\left.22^{\prime} \mathrm{N}, 105^{\circ} 13^{\prime} \mathrm{E}\right)$ [5], $200 \mathrm{~m}$ a.s.1., 11-26.04.2000, A.V. Abramov.

COMMENTS. Known from China and Taiwan [WSC, 2017]; in Vietnam, recorded from Ha Giang Province, Phu Tho Province and $\mathrm{Ha}$ Tinh Province [Pham Dinh et al., 2007; present data]. Song et al. [1999] is the most recent publication to illustrate the species.

\section{Macracantha arcuata (Fabricius, 1793) Map.}

MATERIAL. VIETNAM: 1 Pjuv. (MMUE, G7579.6), Kom Tum Prov., Kon Plong Distr., c. $14 \mathrm{~km} \mathrm{~N}$ of Kon Plong Town $\left(14^{\circ} 43^{\prime} 20^{\prime \prime} \mathrm{N}, 108^{\circ} 18^{\prime} 58^{\prime \prime} \mathrm{E}\right)$ [6], $1030 \mathrm{~m}$ a.s.1., 3-12.06.2016, A.V. Abramov; 1 + 1 Pjuv. (MMUE, G7579.7-8), Gia Lai Prov., c. 40 $\mathrm{km} N$ of K'Bang Town, Kon Chu Rang Nature Reserve $\left(14^{\circ} 30^{\prime} 19^{\prime \prime} \mathrm{N}\right.$, $108^{\circ} 32^{\prime} 28^{\prime \prime}$ ) [7], $1020 \mathrm{~m}$ a.s.1., 24.05-2.06.2016, A.V. Abramov; 1 ojuv. (MMUE, G7579.5), Gia Lai Prov., Mang Yang Distr., c. 42 $\mathrm{km}$ NE of Pleiku, W part of Kon Ka Kinh National Park $\left(14^{\circ} 12^{\prime} 12^{\prime \prime} \mathrm{N}, 108^{\circ} 18^{\prime} 54^{\prime \prime} \mathrm{E}\right)$ [8], $900 \mathrm{~m}$ a.s.1., $10-21.05 .2016$, A.V. Abramov.

COMMENTS. Known from India, China to Borneo [WSC, 2017]; in Vietnam, recorded from Phu Tho Province, Gia Lai Province and Kom Tum Province [Logunov, Jäger, 2015; present data]. Song et al. [1999] is the most recent publication to illustrate the species.

ACKNOWLEDGEMENTS. I would like to thank Dmitri Logunov (MMUE) and Darren Mann (OUMNH) for assistance with the publication, Kirill Mikhailov (ZMMU) for sorting out and giving access to the Gasteracanthinae material from his museum, and Katherine Child (OUMNH) for assistance with the photography and mapping.

\section{References}

Doleschall L. 1859. Tweede Bijdrage tot de Kenntis der Arachniden van den Indischen Archipel // Acta Societatis Scientiarum Indica-Neerlandica. Vol.5. P.1-60.

Hogg H.R. 1922. Some spiders from south Annam // Proceedings of the Zoological Society of London. 1922. P.285-312.

Koch C.L. 1837. Die Arachniden. Dritter Band [6] Nürnberg: C.H. Zeh'sche Buchhandlung. S.105-119; Vierter Band. 108 S.

Logunov D.V., Jäger P. 2015. Spiders from Vietnam (Arachnida: Aranei): new species and records // Russian Entomological Journal. Vol.24. No.4. P.343-363.

Ono H., Thinh T.H., Sac P.D. 2012. Spiders (Arachnida, Araneae) recorded from Vietnam, 1837-2011 // Memoirs of the National Museum of Nature and Science Tokyo. Vol.48. P.1-37.

Pham Dinh S., Xu X., Li S.Q. 2007. A preliminary note on spider fauna of Vietnam (Arachnida: Araneae). // Acta Arachnologica Sinica. Vol.16. No.2. P.121-128.

Roy T.K., Saha S., Raychaudhuri D. 2017. On the araneid fauna (Araneae: Araneidae) of the tea estates of Dooars, West Bengal, India // World Scientific News. Vol.67. No.1. P.1-67.

Sen S., Dhali D.C., Saha S., Raychaudhuri D. 2015. Spiders (Araneae: Arachnida) of Reserve Forests of Dooars: Gorumara National Park, Chapramari Wildlife Sanctuary and Mahananda Wildlife Sanctuary // World Scientific News. Vol.20. P.1-339.

Simon E. 1886. Arachnides recueillis par M. A. Pavie (sous-chef du servis des postes au Cambodge) dans le royaume de Siam, au Cambodge et en Cochinchine // Actes de la Société linnéenne de Bordeaux. T.40. P.137-165.

Simon E. 1904. Arachnides recueillis par M. A. Pavie en Indochine // Mission Pavie en Indochine 1879-1895. III. Recherches sur l'histoire naturells de 1'Indochine Orientale. Paris. P.270-295.

Simon E. 1909. Étude sur les Arachnides de Tonkin (1ere partie) // Bulletin de la Société entomologique de Belgique. Vol.42. P.69-147.

Song D.X., Zhu M.S., Chen J. 1999. The Spiders of China. Shijiazhuang: Hebei University of Science and Techology Publishing House. 640 pp.

Thorell T. 1859. Nya exotiska Epeirider // Öfversigt af Kongliga Vetenskaps-Akademiens Förhandlingar. Bd.16. S.299-304.

Thorell T. 1881. Studi sui Ragni Malesi e Papuani. III. Ragni dell'Austro Malesia e del Capo York, conservati nel Museo civico di storia naturale di Genova // Annali del Museo Civico di Storia Naturale di Genova. Vol.17. P.1-727.

WSC 2017. World Spider Catalog. Natural History Museum Bern, online at: http://wsc.nmbe.ch, version 18.0 (accessed on 18.04 . 2017).

Yin C.M., Peng X.J., Yan H.M., Bao Y.H., Xu X., Tang G., Zhou Q.S., Liu P. 2012. Fauna Hunan: Araneae in Hunan, China. Changsha: Hunan Science and Technology Press. 1590 pp.

Responsible editor D.V. Logunov 